\title{
PENINGKATAN SIFAT FISIKA KIMIA MEMBRAN SELULOSA ASETAT MENGGUNAKAN POLIFUNGSIONAL MONOMER TRIMETHALLYL ISOCYANURATE
}

\author{
Meri Suhartini ${ }^{1}$, Santoso. $P^{1}$, E. Ernawati ${ }^{2}$, dan A.Y.Panjaitan ${ }^{2}$ \\ ${ }^{1}$ Pusat Aplikasi Isotop Radiasi, PAIR-BATAN \\ Jl. Lebak Bulus Raya no.49 Jakarta \\ ${ }^{2}$ Fakultas Matematika dan Ilmu Pengetahuan Alam \\ Universitas Padjadjaran, Jatinangor-Bandung \\ E-mail : meri@batan.go.id
}

3 Januari 2019; 28 Mei 2019; 31 Maret 2020

\begin{abstract}
ABSTRAK
PENINGKATAN SIFAT FISIKA KIMIA MEMBRAN SELULOSA ASETAT MENGGUNAKAN POLIFUNGSIONAL MONOMER TRIMETHALLYL ISOCYANURATE. Membran selulosa asetat dapat digunakan untuk pemurnian minyak atsiri menggunakan teknik pemisahan non pori, akan tetapi membran ini mempunyai sifat fisika dan kimia yang rendah, sehingga mudah koyak dan rusak saat digunakan. Penelitian ini bertujuan untuk meningkatkan sifat fisika dan kimia membran selulosa asetat menggunakan polifungsional monomer Trimethallyl isocyanurate $(T M A / C)$. Membran tersebut diharapkan mempunyai kekuatan tarik tinggi dan derajat penggembungan rendah, sehingga memenuhi kriteria untuk digunakan pada pemurnian minyak atsiri. Selulosa asetat-TMAIC disintesis dengan cara mengisolasi selulosa dari sekam padi, kemudian dibuat selulosa asetat menggunakan asam asetat glasial. Polifungsional monomer TMAIC ditambahkan sebagai agen pengikat silang. Sinar gamma digunakan sebagai inisiator reaksi pembentukan ikatan silang antara selulosa-TMAIC-selulosa. Hasil penelitian menunjukkan bahwa penambahan TMAIC pada selulosa asetat yang digabungkan dengan iradiasi sinar gamma, menyebabkan penurunan derajat penggembungan dan peningkatan kekuatan tarik secara signifikan, yaitu masing-masing sebesar 65,48\% dan 53,24\%. Karakterisasi menggunakan Fourier Transform Infrared (FTIR) membuktikan adanya pembentukan ikatan silang selulosa asetat dengan TMAIC.
\end{abstract}

Kata kunci : Membran selulosa asetat, TMAIC, Ikatan silang, Sinar gamma

\begin{abstract}
IMPROVING THE PHYSICAL AND CHEMICAL PROPERTIES OF ACETIC CELLULOSE MEMBRANE USING POLY-FUNCTIONAL MONOMER TRIMETHALLYL ISOCYANURATE. Cellulose acetate-membranes synthesized from rice husks can be used for purification of essential oils, but these membranes have physical and chemical properties that do not qualify as membranes because they are fragile and easily torn. Aim of this study is to improve the physical and chemical properties of cellulose acetate membranes using polyfunctional monomers - Trimethallyl isocyanurate (TMAIC). It is expected that the membrane has high tensile strength and low degree of swelling, so that it meets the criteria for use in refining essential oils. Cellulose acetate-TMAIC was synthesized by isolating cellulose from rice husks and then made cellulose acetate using glacial acetic acid. Polyfunctional monomer TMAIC was added as crosslinking agent. While gamma rays are used as an initiator of the reaction of crosslinking between cellulose-TMAIC-cellulose. The results showed that the addition of TMAIC to cellulose acetate coupled with gamma ray irradiation caused a significant decrease in the degree of swelling and an increase in tensile strength which are $65.48 \%$ and $54.24 \%$ respectively. Characterization of the sample by Fourier Transform Infrared (FTIR) analysis proven the formation of crosslinking of cellulose acetate with TMAIC.
\end{abstract}

Keywords : Cellulose acetate membrane, TMAIC, Crosslinking, Gamma rays

\section{PENDAHULUAN}

Selulosa asetat hasil asetilasi dari selulosa sekam padi dapat dimanfaatkan, salah satunya sebagai bahan pembuatan membran. Zhou et al., 2013 dalam penelitiannya memanfaatkan selulosa asetat menjadi membran untuk pervaporasi campuran etanol-air dan etanol MTBE (methyl tert-butyl eter) (Zhou et al. 2013). Pada membran untuk pervaporasi, membran hidrofilik banyak digunakan untuk pelarut organik (Jyoti, Keshav, and Anandkumar 
2015). Kelemahan membran selulosa asetat untuk pervaporasi adalah kinerja yang rendah karena dapat menggembung, disebabkan adanya volume bebas yang terisi umpan dan mengurangi selektivitas dari membrane, serta mudah robek karena kekuatan tariknya yang rendah. Untuk meningkatkan kinerja dari membran selulosa asetat ini, diperlukan modifikasi. Ikatan silang merupakan salah satu modifikasi pada membran dan dapat meningkatkan selektivitas pada membran, namun mengurangi fluks (Lee et al. 2016). Ikatan silang dilakukan pada PBS (polybutylene succinate) menggunakan TMAIC sebagai monomer dan diiradiasi dengan sinar- $\mathrm{\gamma}$, dapat meningkat sifat fisik serta ketahanan panas dari PBS.

Komponen utama dinding sel pada sekam padi adalah selulosa. Kandungan selulosa yang cukup besar (40\% sampai dengan 50\%) ini menjadikan sekam padi sebagai sumber selulosa yang cukup potensial, selain itu adanya silika (Das, Ali, and Hazarika 2014). Selulosa merupakan homo polimer dari D-anhidroglukosa (glukosa anhidrida) dengan ikatan $\beta-1-4-$ glukosida yang memiliki rumus empiris $\left(\mathrm{C}_{6} \mathrm{H}_{12} \mathrm{O}_{5}\right) \mathrm{n}$, dimana $\mathrm{n}$ adalah jumlah satuan glukosa yang berikatan atau menyatakan derajat polimerisasi yang berkisar antara 15 sampai dengan 1400 (Bhattacharya and Mandal 2018).

Proses pengikatan silang merupakan salah satu metode untuk memperbaiki sifat fisik dan kimia membran (Suhartini 2014). Ukuran molekul crosslinker yang kecil akan cepat melakukan reaksi sambung silang, karena proses difusi lebih mudah. Hal ini tergantung pada sifat dari crosslinker itu sendiri, interaksi utama pembentukan jaringan adalah ikatan kovalen atau ionik (Sedlacek et al. 2017). Pembentukan film pada umumnya melibatkan kumpulan inter- dan intra- molekul atau ikatan silang (crosslinking) rantai polimer membentuk jaringan 3D setengah kaku (Suhartini 2014).

Pembentukan ikatan silang yang disebabkan oleh adanya reaksi rekombinasi antara makro-radikal akan meningkatkan kekuatan dan modulus plastik (Suhartini 2014). Pada penelitian ini, inisiator yang digunakan dalam reaksi pembentukan ikatan silang adalah sinar gamma.

Trimethallyl isocyanurate (TMAIC) merupakan polifungsional monomer atau monomer yang memiliki beberapa gugus fungsi, selain itu juga dikenal sebagai monomer triazina trifungsional dengan kecenderungan yang sangat rendah untuk homopolimerisasi serta memiliki stabilitas termal yang tinggi dibandingkan dengan agen pengikat silang yang lain seperti TAIC (Triallyl isocyanurate) (Suhartini 2014). TMAIC memiliki tekanan uap rendah bahkan pada suhu tinggi dan stabil, walaupun dengan adanya asam air dan mineral. TMAIC mempunyai unit siklik yang lebih mudah membentuk ikatan silang tiga dimensi dengan menggunakan iradiasi dibandingkan alipatik polifungsional monomer lainnya (Suhartini 2014). Struktur umum TMAIC ditunjukkan pada Gambar 1.

Pervaporasi dipandang sebagai alternatif ekonomi untuk beberapa proses pemisahan klasik, seperti ekstraksi cair-cair, distilasi (azeotropik, ekstraktif, fraksional), dan untuk memurnikan campuran yang pemisahannya sulit atau mahal dengan metode klasik (Silvestre et al. 2019).

Berdasarkan data dan penelitian yang sudah dilakukan tersebut diatas, maka dilakukan isolasi selulosa dari sekam padi dan dibuat membran selulosa asetat- TMAIC menggunakan inisiator iradiasi sinar gamma. Membran selulosa asetat-TMAIC yang dihasilkan, diharapkan mempunyai sifat fisik dan kimia yang memenuhi syarat untuk membran pemisah, sehingga dapat digunakan secara optimal untuk pemurnian minyak atsiri. Maksud dari penelitian ini adalah untuk membuat membran selulosa asetat-TMAIC dari sekam padi yang mempunyai kuat tarik tinggi dan rasio pengembangan rendah, sehingga dapat digunakan untuk pemurnian minyak atsiri khususnya untuk meningkatkan kadar vetiverol dari minyak akar wangi melalui proses pervaporasi. Pada penelitian ini, dilakukan isolasi selulosa dari sekam padi, sintesis membran, dan karakterisasi membran yang dihasilkan menggunakan FTIR. Hasil penelitian ini diharapkan dapat diaplikasikan sebagai membran pervaporasi untuk pemurnian minyak atsiri, khususnya untuk meningkatkan kadar vetiverol pada minyak akar wangi. Selain itu, dapat memberikan nilai ekonomis terhadap pemanfaatan limbah penggilingan padi (sekam padi).

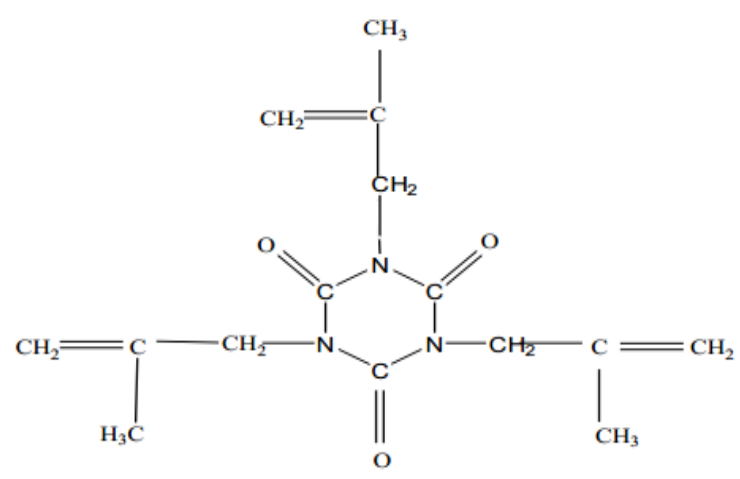

Gambar 1. Struktur TMAIC (Suhartini 2014). 


\section{BAHAN DAN METODE}

\section{Bahan}

Bahan-bahan yang digunakan adalah sekam hasil penggilingan padi dari Desa Gegerkalong, Bandung, akuades, anhidrida asetat p.a (Merck), asam asetat glasial (Merck), hidrogen peroksida (Merck), asam klorida (Merck), asam nitrat (Merck), asam sulfat (Merck), asam oksalat, aseton, etanol (Merck), heksana (Merck), indikator fenoftalein (Merck), kalium hidroksida (Merck), kalium karbonat (Merck), magnesium sulfat heptahidrat (Merck), metanol (Merck), metilen klorida (Merck), natrium asetat anhidrat (Merck), natrium hidroksida (Merck), natrium karbonat (Merck), dan natrium klorida.

Alat-alat yang digunakan pada penelitian ini adalah alat-alat gelas yang biasa digunakan di laboratorium, Fourrier Transform Infrared Spectroscopy (FTIR) perkin Elmer Spektrum 100, magnetic stirrer, Instron Sterograph R1, dan termometer.

\section{Metode}

Isolasi Selulosa dari Sekam Padi (Erawati et al. 2016, Wang et al. 2016)

Sekam padi dioven pada suhu $110{ }^{\circ} \mathrm{C}$ selama 24 jam untuk menghilangkan kadar air. Sekam padi kemudian direflux selama 6 jam dengan heksan : etanol (2:1) dengan rasio 1:10. Setelah itu, sekam padi disaring dan dikeringkan selama 16 jam pada suhu $55^{\circ} \mathrm{C}$. Sekam lalu didispersikan pada suhu $45^{\circ} \mathrm{C}$ selama 15 jam dalam larutan hidrogen peroksida $1,5 \%$ yang diatur hingga $\mathrm{pH} 12$ menggunakan natrium hidroksida $1 \mathrm{~N}$, kemudian dilanjutkan dengan pencucian menggunakan etanol dan akuades (2:1) hingga $\mathrm{pH}$ netral lalu disaring. Setelah itu, residu (crude cellulose) dikeringkan selama 16 jam pada suhu $55^{\circ} \mathrm{C}$. Crude cellulose yang dihasilkan, didispersikan dalam asam asetat $80 \%$ dan asam nitrat $70 \%$ (10:1) pada suhu $120{ }^{\circ} \mathrm{C}$ selama 15 menit. Setelah itu dicuci dengan etanol dan akuades, lalu disaring. Proses selanjutnya diulangi dengan mendispersikannya dalam larutan hidrogen peroksida 1,5\% yang diatur hingga $\mathrm{pH} 12$ menggunakan natrium hidroksida $1 \mathrm{~N}$ yang dilanjutkan dengan pencucian menggunakan etanol dan akuades (2:1) hingga netral lalu disaring. Setelah itu residu (crude cellulose) dikeringkan selama 16 jam pada suhu $55^{\circ} \mathrm{C}$. Residu selulosa yang dihasilkan dikeringkan pada suhu $55^{\circ} \mathrm{C}$ selama 16 jam dan ditimbang.

\section{Pembuatan Selulosa Asetat}

Sebanyak $4 \mathrm{~g}$ selulosa ditambah $50 \mathrm{~mL}$ asam asetat glasial diaduk selama 1 jam pada suhu kamar. Setelah itu, ditambahkan $30 \mathrm{~mL}$ asam asetat anhidrida dan 2 tetes asam sulfat pekat kemudian diaduk selama 3 jam, lalu ditambahkan sebanyak $10 \mathrm{~mL}$ asam asetat glasial $60 \%$ tetes demi tetes. Selanjutnya, didiamkan selama 42 jam. Larutan disaring dan filtratnya ditambahkan akuades hingga terbentuk endapan (berwarna putih). Endapan disaring dan dikeringkan dalam oven pada suhu $50{ }^{\circ} \mathrm{C}$ selama 24 jam (Ernawati 2016).

\section{Penentuan Kadar Asetil}

Sampel sebanyak $1 \mathrm{~g}$ diberi $40 \mathrm{~mL}$ etanol, dipanaskan pada suhu $60^{\circ} \mathrm{C}$ selama 30 menit. Setelah itu, ditambahkan $40 \mathrm{~mL}$ larutan natrium hidroksida $0,5 \mathrm{M}$, dipanaskan pada suhu $60^{\circ} \mathrm{C}$ selama 15 menit. Erlenmeyer ditutup rapat dan campuran larutan didiamkan selama 72 jam pada suhu ruang. Campuran larutan kemudian ditetesi indikator fenolftalein, dititrasi dengan asam klorida 0,462 M, dan ditambahkan $1 \mathrm{~mL}$ asam klorida 0,47 M. Campuran dibiarkan selama 24 jam. Setelah itu, ditetesi indikator fenolftalein dan dititrasi dengan natrium hidroksida 0,5 M. Untuk mengetahui kadar asetil digunakan persamaan 1. (Ernawati 2016).

$\mathrm{Ka}(\%)=\left\{[(\mathrm{D}-\mathrm{C}) \mathrm{Na}+(\mathrm{A}-\mathrm{B}) \mathrm{Nb}]\left(\frac{\mathrm{F}}{\mathrm{W}}\right)\right\} \times 100 \%$

\section{Keterangan :}

A = volume natrium hidraoksida yang dibutuhkan untuk titrasi sampel/ $\mathrm{mL}$

$\mathrm{B}=$ volume natrium hidroksida yang dibutuhkan untuk titrasi blanko/ $\mathrm{mL}$

C = volume asam klorida yang dibutuhkan untuk titrasi sampel/ $\mathrm{mL}$

$\mathrm{D}=$ volume asam klorida yang dibutuhkan untuk titrasi blanko/ $\mathrm{mL}$

$\mathrm{Na}=$ normalitas asam klorida $/ \mathrm{M}$

$\mathrm{Nb}=$ normalitas natrium hidroksida/ $\mathrm{M}$

$\mathrm{F} \quad=$ Nilai 4,305

$\mathrm{W}=$ massa sampel $/ \mathrm{g}$

\section{Sintesa Selulosa Asetat-TMAIC}

Sebanyak $4 \mathrm{~g}$ selulosa asetat dimasukkan ke dalam labu erlenmeyer $50 \mathrm{~mL}$ yang berisi aseton $16 \mathrm{~g}(\mathrm{~b} / \mathrm{b})$ secara perlahan sambil diaduk dengan menggunakan pengaduk magnetik. Larutan diaduk selama 24 jam, kemudian dimasukkan dalam lemari pendingin selama 24 jam. Setelah itu, dicetak dalam plat kaca, lalu direndam dengan larutan TMAIC $1 \%$ dan kemudian diiradiasi menggunakan sinar gamma pada dosis 20 kGy, 30 kGy, dan 40 kGy.

\section{Karakterisasi Membran SA -TMAIC Penentuan derajat penggembungan}

Membran selulosa asetat-TMAIC yang telah dibuat, direndam dalam larutan umpan (minyak akar wangi) selama 24 jam. Setelah cairannya dipanaskan, membran dikeringkan dan ditimbang sampai diperoleh berat yang konstan, kemudian dihitung DP. Setelah 
diketahui berat membran basah dan kering yang konstan, derajat penggembungan ditentukan menggunakan persamaan berikut:

$$
\% \mathrm{DP}=\frac{\mathrm{W}_{2}-\mathrm{W}_{1}}{\mathrm{~W}_{1}} \times 100
$$

$\mathrm{W}_{1}$ = bobot selulosa sebelum direndam (gram)

$\mathrm{W}_{2}$ = bobot selulosa setelah direndam (gram)

\section{Penentuan Kekuatan Tarik (TS)}

Membran selulosa asetat-TMAIC dipotong sesuai plat dengan lebar $0,3 \mathrm{~cm}$, lalu diukur ketebalannya, dan diuji kekuatan tariknya dengan menggunakan alat Stograph-RJ, Toseiki menggunakan speed 25.

\section{Analisis Fourrier Transform Infrared (FTIR)}

FTIR digunakan untuk mengetahui komposisi kimia dari membran-membran yang dibuat dengan menganalisis gugus-gugus fungsi dari membran. FTIR yang digunakan adalah FTIR perkin Elmer pada spektrum 450 sampai dengan 4000.

\section{HASIL DAN PEMBAHASAN}

\section{Sintesis Selulosa Asetat}

Kadar asetil dari selulosa asetat yang telah disintesis adalah 42,2\%. Selulosa asetat dengan kadar asetil tersebut merupakan selulosa diasetat. Selulosa asetat dengan kandungan asetil kurang dari $36,5 \%$ adalah selulosa monoasetat, kadar asetil $36,5 \%$ sampai dengan $43,5 \%$ adalah selulosa diasetat, dan kadar asetil 43,5\% sampai dengan 44,8\% merupakan selulosa triasetat (Vaulina et al. 2018). Proses pembuatan selulosa asetat terdiri dari tiga tahap, yaitu tahap swelling, tahap asetilasi, dan tahap hidrolisis (deasetilasi). Pada tahap swelling, terjadi penggembungan pada serat selulosa agar lebih terbuka sehinga mudah bereaksi dengan asetat anhidrat. Pada tahap asetilasi digunakan katalis asam sulfat supaya gugus hidroksil cepat bereaksi dengan anhidrida asetat. Suhu juga harus dikontrol karena reaksi berjalan eksoterm dan reaksi harus berjalan pada suhu rendah. Pada tahap asetilasi selulosa asetat yang dihasilkan merupakan triasetat. Pada tahap hidrolisis, selulosa triasetat mengalami deasetilasi menjadi diasetat.

\section{Pengaruh Variasi Konsentrasi TMAIC}

Pembentukan fraksi gel menggambarkan seberapa banyak terjadi kopolimerisasi ikatan silang, pada Gambar 2 dan Gambar 3 dapat dilihat bahwa penambahan TMAIC berpengaruh pada pembentukan ikatan silang. Pada konsentrasi TMAIC yang meningkat sampai dengan $1 \%$, derajat kopolimerisasi ikatan silang meningkat, kemudian menurun pada konsentrasi TMAIC 1,5\%. Hal ini disebabkan pada konsentrasi TMAIC yang tinggi akan terjadi lebih banyak radikal pada TMAIC itu sendiri yang mendorong pembentukan homopolimer pada $T M A I C$, yang pada akhirnya mengurangi TMAIC yang berikatan dengan selulosa asetat. Seperti diketahui (Suhartini 2014) selulosa asetat termasuk polimer yang cenderung degradasi apabila diradiasi, kecenderungan degradasi ini dapat diatasi dengan menambahkan polifungsional monomer, dimana radikal yang terbentuk mendorong pembukaan ikatan rangkap yang kemudian berikatan dengan TMAIC sebagai agen pengikat silang.

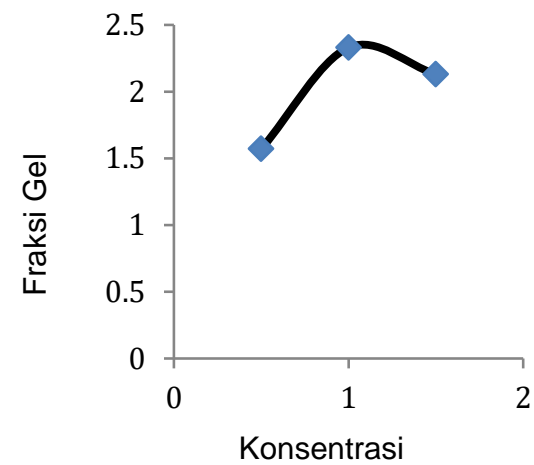

Gambar 2. Pengaruh konsentrasi TMAIC pada fraksi gel
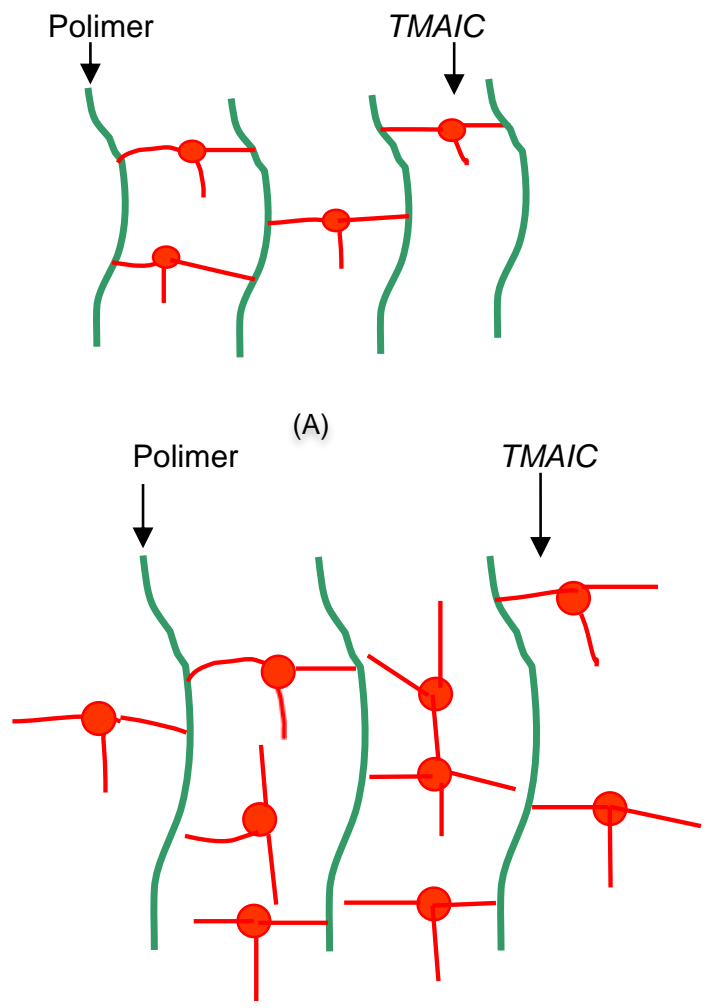

(B)

Gambar 3. Model penggambaran pengaruh konsentrasi TMAIC sebagai agen pengikat silang pada polimer, A. Polimer dengan penambahan TMAIC $1 \%$ dan B. Polimer dengan penambahan TMAIC 1,5\% 


\section{Derajat Penggembungan dan Fraksi Gel}

Salah satu metode untuk mengetahui kerapatan membran adalah dengan mengukur derajat penggembungan pada membran (Ernawati 2016). Hasil penentuan derajat penggembungan dapat dilihat pada Gambar 4.

Dari Gambar 4. dapat dilihat terdapat penurunan derajat penggembungan secara signifikan dari $8,14 \%$ menjadi $3,41 \%$ dan optimum pada dosis iradiasi $30 \mathrm{kGy}$. Pada dosis iradiasi 40kGy, derajat penggembungan kembali naik. Hal ini disebabkan pada dosis yang tinggi, terjadi degradasi kerangka selulosa asetat akibat reaksi pemutusan rantai. Polimer selulosa asetat tergolong dalam kelas polimer terdegradasi dengan proses radiasi akibatnya kerapatan membran menurun dan derajat penggembungan meningkat.
Nilai DP dipengaruhi pula oleh fraksi gel atau derajat kopolimerisasi yang terbentuk selama proses iradiasi. Fraksi gel merupakan derajat banyaknya ikatan silang yang terbentuk antara TMAIC dan selulosa asetat. Nilai DP yang menurun pada membran tersebut disebabkan bertambahnya ikatan silang yang terbentuk.

Pada Gambar 5 dapat dilihat bahwa fraksi gel meningkat dengan adanya peningkatan dosis iradiasi dan mencapai maksimum pada dosis 30 kGy. Pada dosis iradiasi 40 kGy terjadi penurunan fraksi gel, hal ini disebabkan selain karena adanya degradasi pada rantai utama selulosa juga karena selulosa termasuk polimer yang cenderung terdegradasi.

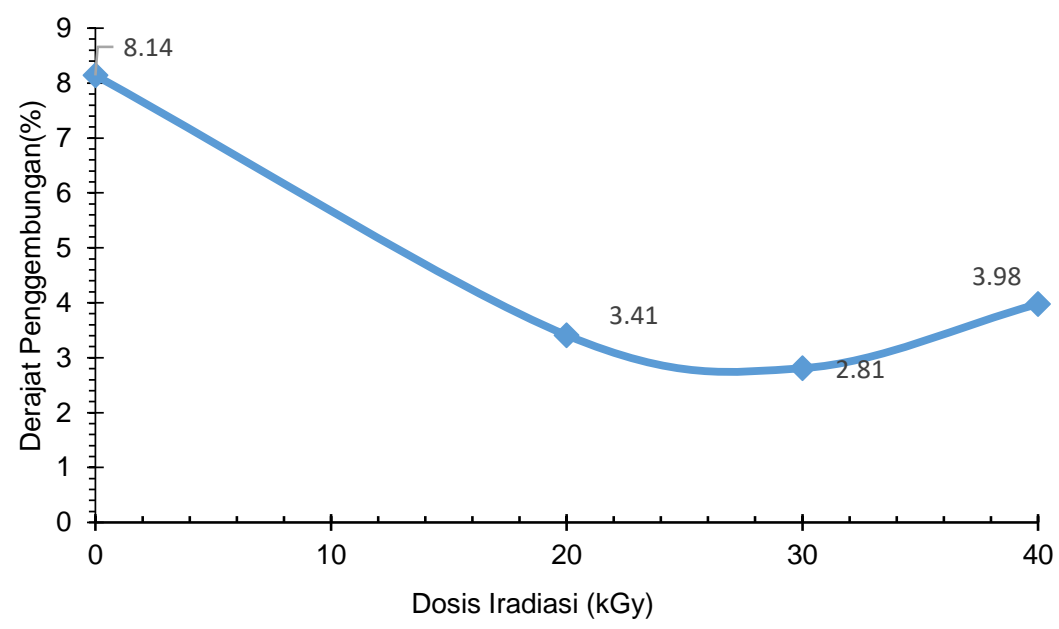

Gambar 4. Grafik derajat penggembungan membran selulosa asetat-TMAIC

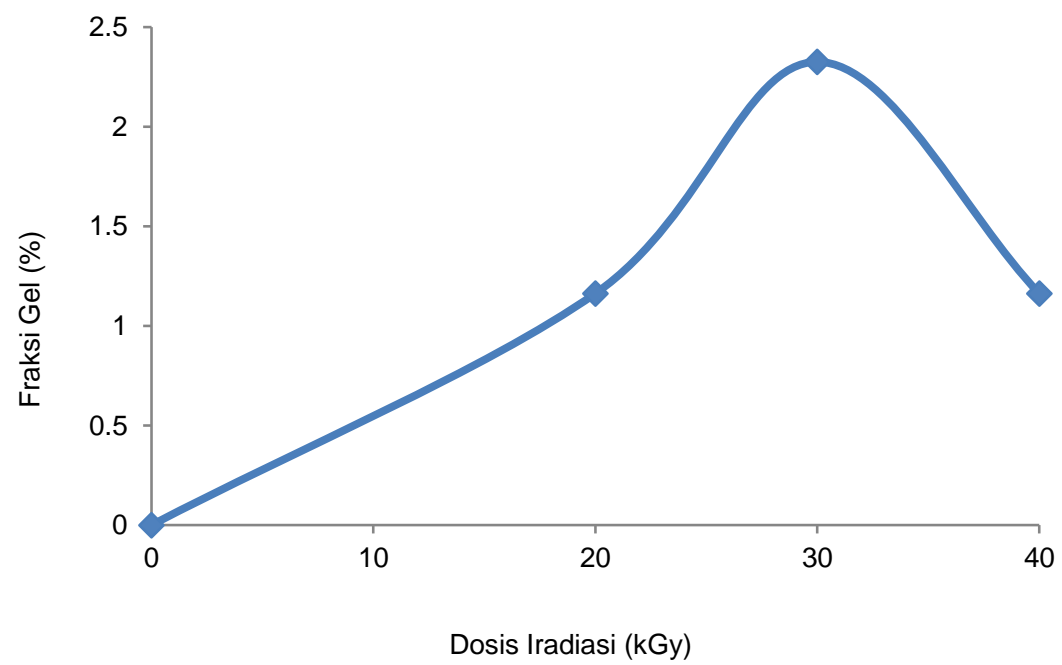

Gambar 5. Grafik fraksi gel membran selulosa asetat- TMAIC pada konsentrasi TMAIC 1\% 
Dari Gambar 4 dan Gambar 5 dapat dilihat bahwa nilai DP berbanding terbalik dengan jumlah fraksi gel yang dihasilkan. Hal ini karena semakin meningkatnya fraksi gel, maka semakin banyak ikatan silang yang terbentuk, yang akan menahan terjadinya difusi cairan ke dalam pori membran (Gambar 6). Hal ini dibuktikan pada keadaan membran selulosa asetat (SA) awal yang tidak terikat silang, derajat penggembungan yang diperoleh sebesar $8,14 \%$. Namun ketika membran SA-TMAIC mengalami ikatan silang pada dosis radiasi-y 20 kGy dan 30 kGy, DP menurun menjadi $3,41 \%$ dan $2,81 \%$ yang artinya nilai fraksi gel mempengaruhi DP pada membran SA.

\section{Kekuatan Tarik}

Modifikasi membran SA menyebabkan terjadinya perubahan sifat mekanik yang ditunjukkan dari hasil pengujian kekuatan tarik (TS). TS merupakan salah satu parameter untuk mengetahui sifat mekanik dari membran.
Pada Gambar 7, TS dari membran SA bertambah dengan meningkatnya dosis radiasi sampai pada titik dimana peningkatan dosis radiasi menyebabkan terjadinya degradasi pada selulosa, yaitu pada dosis radiasi 40 kGy.

Semakin tinggi dosis radiasi yang digunakan, maka TS semakin besar karena terjadi ikatan silang pada bagian amorphous pada membran SA dengan adanya polifungsional monomer TMAIC, akan tetapi pada dosis iradiasi $40 \mathrm{kGy}$ terjadi degradasi pada selulosa yang menyebabkan TS menurun. Hasil TS optimum yaitu $354,44 \mathrm{~kg} \cdot \mathrm{cm}^{-2}$ pada penambahan TMAIC dengan dosis radiasi 30kGy, sedangkan pada dosis radiasi 40 kGy TS turun menjadi $296,48 \mathrm{~kg} \cdot \mathrm{cm}^{-2}$. Penurunan TS terjadi karena selulosa asetat terdegradasi. Pada dosis iradiasi yang tinggi terjadi degradasi pada kerangka selulosa asetat akibat reaksi pemutusan rantai, karena selulosa asetat tergolong dalam kelas polimer terdegradasi dengan proses radiasi (Suhartini 2014).

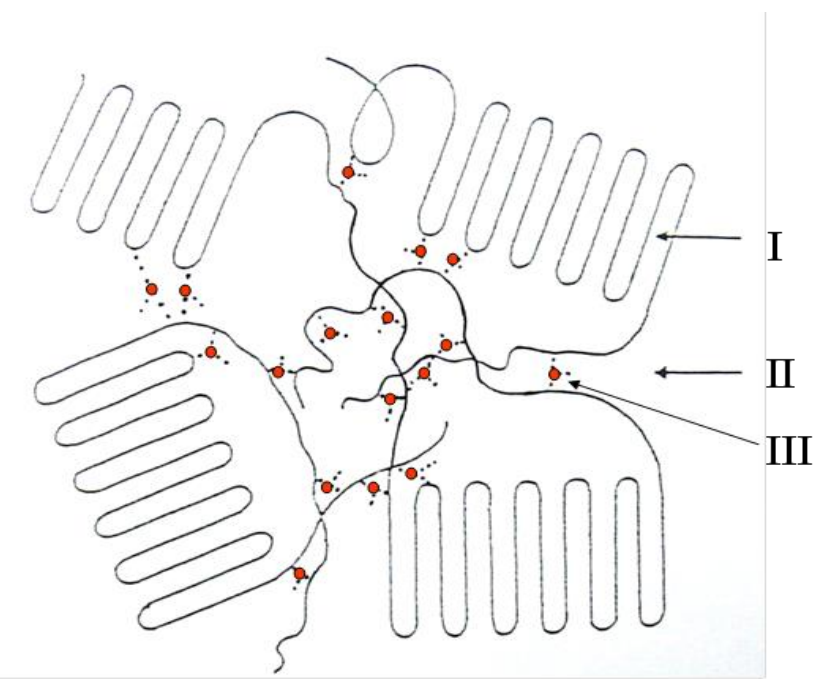

Gambar 6. Model penggambaran TMAIC sebagai agen pengikat silang pada polimer, semakin banyak ikatan silang yang terbentuk, maka semakin besar fraksi gel yang dihasilkan. (I.Bagian kristalin, II. Bagian amorf, dan III. TMAIC sebagai pengikat silang) (Suhartini, 2003)

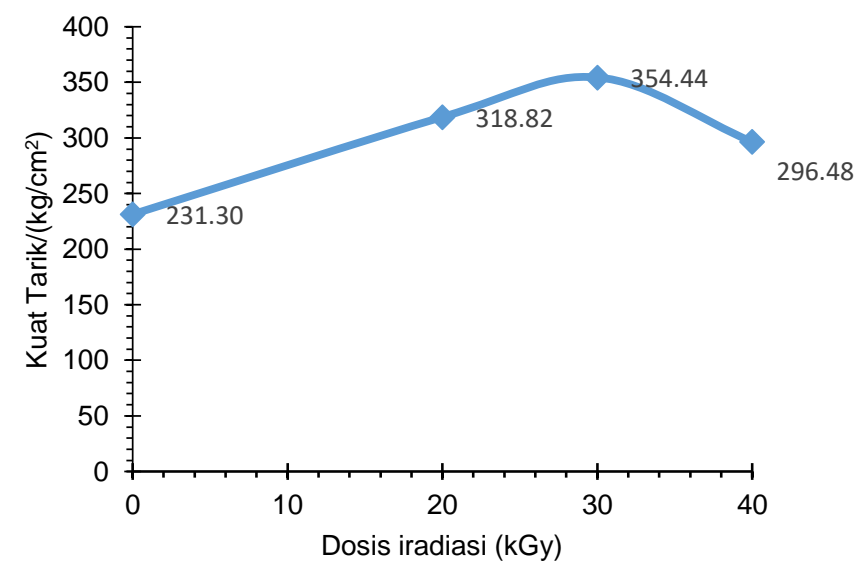

Gambar 7. Grafik kekuatan tarik membran SA-TMAIC 


\section{Analisis Gugus Fungsi}

Pada Gambar

8. dapat dilihat perbandingan spektra FTIR antara membran SA (A) dan membran SA-TMAIC (B). Berdasarkan hasil pada spektra $B$, terjadi pergeseran puncak pada beberapa bilangan gelombang pada gugus fungsi SA dapat dilihat pada Tabel 1. Pergeseran bilangan gelombang berubah pada gugus fungsi khas selulosa asetat, yaitu serapan dari $-\mathrm{OH}$ pada $3482 \mathrm{~cm}^{-1}$ menjadi $3487 \mathrm{~cm}^{-1}$ dan $\mathrm{C}=\mathrm{O}$ dari $1753 \mathrm{~cm}^{-1}$ menjadi $1727 \mathrm{~cm}^{-1}$.

Pergeseran bilangan gelombang tersebut terjadi karena adanya ikatan silang yang terbentuk pada SA dengan TMAIC (Gambar 9). Pembentukan ikatan silang diinisiasi menggunakan sinar gamma sebagai inisiator, sehingga terjadi reaksi radikal antara SA dan TMAIC. Pembentukan ikatan silang ini diawali dengan tahap inisiasi, yaitu pembentukan radikal bebas -O pada SA yang diinisiasi oleh radiasi sinar-y. Selanjutnya tahap propagasi yang mana akan terjadi sederetan reaksi radikal. Radikal -O• pada SA akan menyerang ikatan rangkap pada TMAIC dan membentuk ikatan sehingga terbentuk ikatan silang. Konsentrasi SA dibuat $10 \% \quad(\mathrm{~b} / \mathrm{v})$ terhadap aseton karena pada konsentrasi tersebut mampu menghasilkan membran dengan struktur morfologi dan sifat mekanik yang cukup baik (Ernawati 2016).

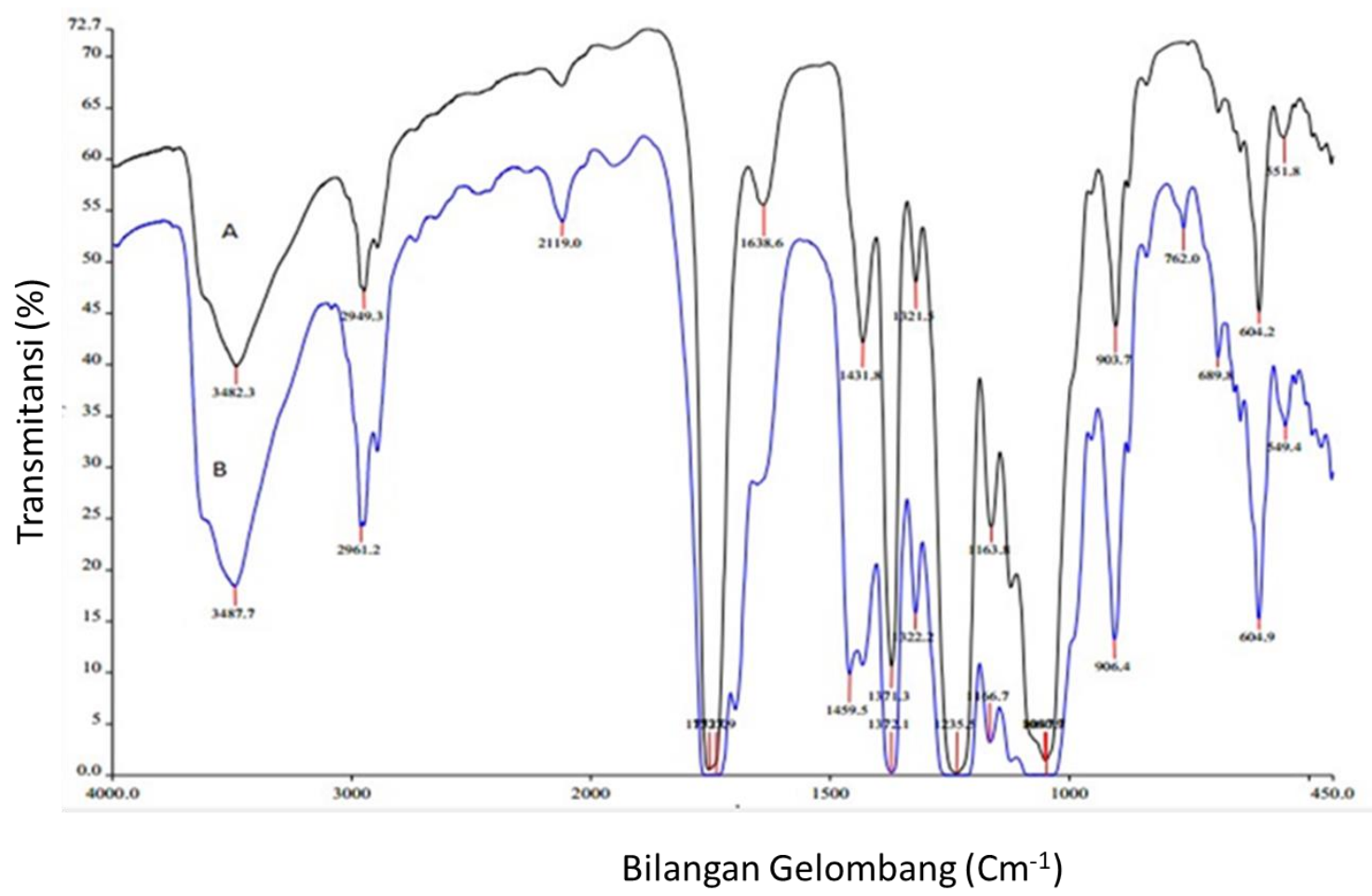

Gambar 8. Spektra FTIR membran SA (A) dan SA-TMAIC (B)

Tabel 1. Hasil analisis FTIR membran SA(A) dan membran SA-TMAIC

\begin{tabular}{cccc}
\hline Gugus fungsi & $\begin{array}{c}\text { Bilangan gelombang } \\
\text { literatur } \\
\left(\mathrm{cm}^{-1}\right)\end{array}$ & $\begin{array}{c}\text { Bilangan gelombang } \\
\text { membran SA(A) } \\
\left(\mathrm{cm}^{-1}\right)\end{array}$ & $\begin{array}{c}\text { Bilangan gelombang } \\
\text { membran SA-TMAIC } \\
\left(\mathrm{cm}^{-1}\right)\end{array}$ \\
\hline O-H & $3500-3100$ & 3482 & 3487 \\
C-H & $3000-2800$ & 2949 & 2961 \\
C=O & $1750-1600$ & 1753 & 1727 \\
C-O-C & $1100-1000$ & 1164 & 1167 \\
\hline
\end{tabular}




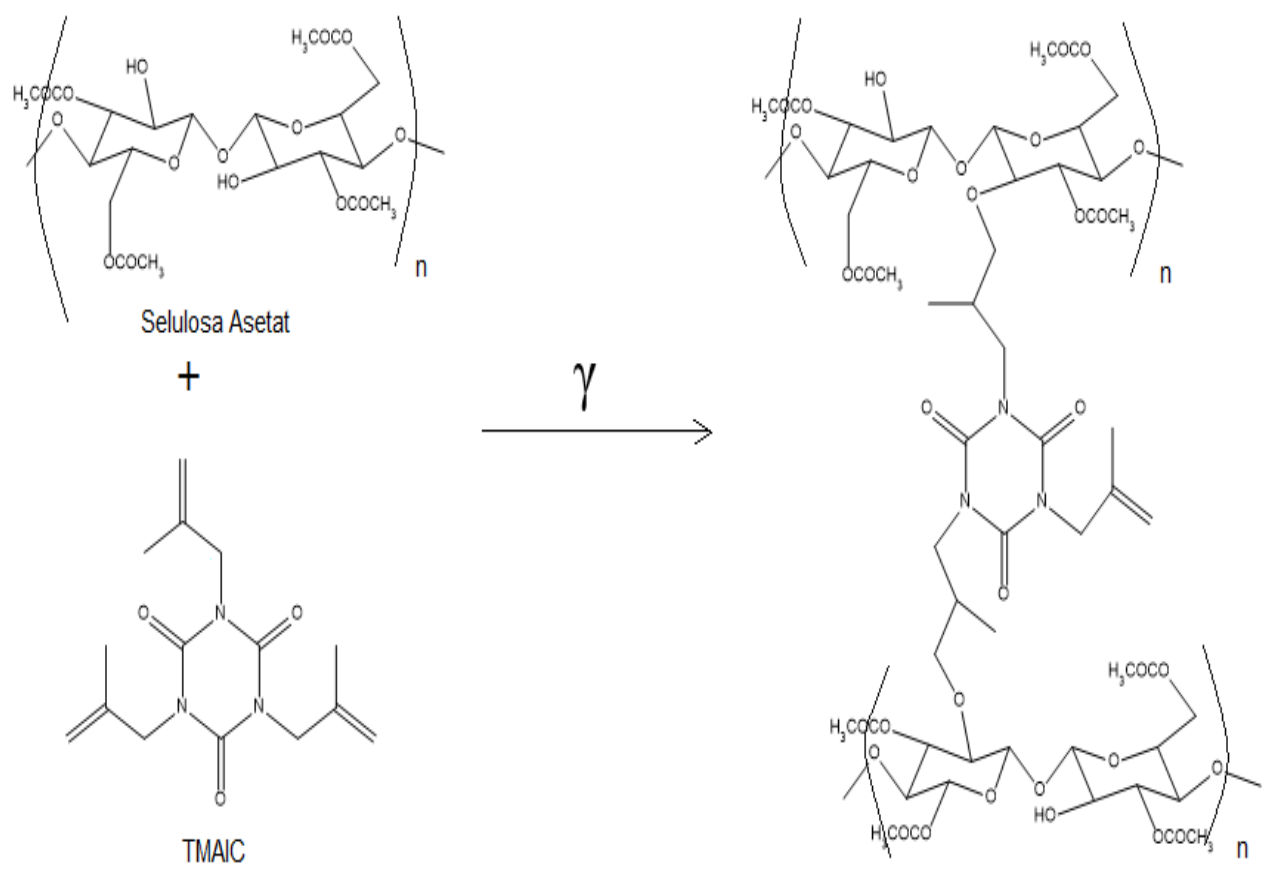

Gambar 9. Model reaksi pembentukan ikat silang antara Selulosa Asetat dan TMAIC

\section{KESIMPULAN}

Pengikatan silang pada membran selulosa asetat dapat dilakukan dengan menambahkan polifungsional monomer TMAIC dan menggunakan inisiator reaksi berupa sinar gamma dari sumber kobal-60. TMAIC berfungsi sebagai jembatan pengikat silang diantara fase amorphous pada polimer. Hasil sintesis membran selulosa asetat-TMAIC mempunyai sifat fisika dan kimia yang lebih baik, hal ini ditunjukan dengan derajat penggembungan (DP) yang lebih rendah dan kekuatan tarik membran lebih tinggi dibandingkan membran selulosa asetat tanpa modifikasi, inilah merupakan tujuan dari modifikasi membran ini. Membran dengan sifat fisika dan kimia terbaik diperoleh pada penambahan $1 \%$ TMAIC dan dosis iradiasi 30 kGy.

\section{UCAPAN TERIMA KASIH}

Penulis mengucapkan terima kasih kepada sdr. Dewi Sekar P (BATAN) atas bantuannya pada pengukuran kekuatan tarik dan sdr. Bonang (BATAN) atas bantuannya untuk mengiradiasi sampel.

M. Suhartini merupakan kontributor utama pada penulisan paper ini.

\section{DAFTAR PUSTAKA}

Bhattacharya, M., and M. K. Mandal. 2018. "Synthesis of Rice Straw Extracted NanoSilica-Composite Membrane for $\mathrm{CO} 2$
Separation." Journal of Cleaner Production 186: 241-52. https://doi.org/10.1016/j.jclepro.2018.03.0 99.

Das, A. M., A. A. Ali, and M. P. Hazarika. 2014. "Synthesis and Characterization of Cellulose Acetate from Rice Husk: EcoFriendly Condition." Carbohydrate Polymers 112: 342-49. https://doi.org/10.1016/j.carbpol.2014.06.0 06.

Ernawati, E. E. 2016. "Sintesis Membran Kopolimerisasi Selulosa AsetatGlutaraldehid Menggunakan Iradiasi Berkas Elektron Untuk Pervaporasi Etanol-Air Pembuatan Membran SA-GA" 17 (2).

Jyoti, G., A. Keshav, and J. Anandkumar. 2015. "Review on Pervaporation: Theory, Membrane Performance, and Application to Intensification of Esterification Reaction." Journal of Engineering (United States) 2015. https://doi.org/10.1155/2015/927068.

Lee, J. S., S. A. Heo, H. J. Jo, and B. R. Min. 2016. "Preparation and Characteristics of Cross-Linked Cellulose Acetate Ultrafiltration Membranes with High Chemical Resistance and Mechanical Strength." Reactive and Functional Polymers 99: 114-21. https://doi.org/10.1016/j.reactfunctpolym.2 015.12.014.

Sedlacek, O., J. Kucka, B. D. Monnery, M. Slouf, M. Vetrik, R. Hoogenboom, and M. Hruby. 
2017. "The Effect of Ionizing Radiation on Biocompatible Polymers: From Sterilization to Radiolysis and Hydrogel Formation." Polymer Degradation and Stability 137: 1-10. https://doi.org/10.1016/j.polymdegradstab. 2017.01.005.

Silvestre, W. P., N. F. Livinalli, C. Baldasso, and I. C. Tessaro. 2019. "Pervaporation in the Separation of Essential Oil Components: A Review." Trends in Food Science \& Technology.

https://doi.org/10.1016/j.tifs.2019.09.003.

Suhartini, M. 2014. "Modification of Biodegradable Polyesters Using Electron Beam." Atom Indonesia 39 (3): 129. https://doi.org/10.17146/aij.2013.255.

Suhartini, M. 2003. "Radiation-Induced Crosslinking of Poly(butylene succinate) and Its Biodegradability" Desertation, Gunma University, Gunma, Japan.

Vaulina, E., S. Widyaningsih, D. Kartika, and M. P. Romdoni. 2018. "The Effect of
Cellulose Acetate Concentration from Coconut Nira on Ultrafiltration Membrane Characters." IOP Conference Series: Materials Science and Engineering 349 (1). $\quad$ https://doi.org/10.1088/1757899X/349/1/012020.

Wang, Z., J. Li, J. P. Barford, K. Hellgradt, and G. Mckay. 2016. "A Comparison of Chemical Treatment Methods for the Preparation of Rice Husk Cellulosic Fibers." International Journal of Environmental \& Agriculture Research 2 (1): 2454-1850.

Zhou, K., Q. G. Zhang, G. L. Han, A. M. Zhu, and Q. L. Liu. 2013. "Pervaporation of Water-Ethanol and Methanol-MTBE Mixtures Using Poly (Vinyl Alcohol)/Cellulose Acetate Blended Membranes." Journal of Membrane Science 448: 93-101. https://doi.org/10.1016/j.memsci.2013.08. 005. 